\title{
Studies on Nutrient Management, Varieties and Moisture Conservation Practices on Growth Parameter, Root Development and WUE in Barley (Hordeum vulgare L.) under Rainfed Condition
}

\author{
Ravi Pratap Singh ${ }^{*}$ and S. C. Katiyar \\ Department of Soil Conservation and Water Management, C.S. Azad University of Agriculture \\ and Technology Kanpur, India \\ *Corresponding author
}

\section{A B S T R A C T}

Keywords

Barley,

Hordeum vulgare, Rainfed Condition

Article Info

Accepted:

12 December 2020

Available Online:

10 January 2021
A field experiment was conducted 2015-16 and 2016-2017 at experiment farm Soil Conservation of Water Management in C.S. Azad University of Agriculture and Technology, Kanpur. The experiment was carried out in factorial complete randomized block design with three replications and three nutrient management i.e. $\mathrm{N}_{1}(100 \% \mathrm{RDN})$, $\mathrm{N}_{2}$ (75\% RDN through chemical fertilizers $+25 \%$ RDN through vermicompost) and $\mathrm{N}_{3}$ (75\% RDN through chemical fertilizers $+25 \%$ RDN through vermicompost + Azotobactor) and two varieties i.e. $\mathrm{V}_{1}$-Narmada (K-603), $\mathrm{V}_{2}$-Azad (K-125) and three level of moisture conservation practices i.e. $\mathrm{M}_{1}$-Control, $\mathrm{M}_{2}$-Dust mulch created by weeding and hoeing followed by hand hoe after 25 days of sowing, $\mathrm{M}_{3}$-Herbicide (2,4-D, 35 days after sowing). Results revealed that $75 \%$ RDN through chemical fertilizer $+25 \%$ RDN through vermicompost + Azotobacter, variety Narmada of barley and dust mulching practices of moisture conservation practices produced significantly more growth parameters, root studies and water use efficiency than the other treatments during both the years of study. The farming majority may be advocated for adoption of 75\% RDN through chemical fertilizer $+25 \%$ RDN through vermicompost + Azotobacter, variety Narmada of barley and dust mulching practices of moisture conservation practices for good productivity and profitability under rainfed farming.

\section{Introduction}

Many crop management factors affect the yield of this crop. It is grown in harsh environments, the potential for meeting growing demand by expanding the area sown is limited. Among the various management practices, the major non monetary inputs for enhancing the barley production is optimum time of sowing and optimum spacing which modifies the growth environment by way of regulating the natural endowments like light, temperature and moisture. Also owing to its hardy nature, it can be successfully cultivated in rainfed areas of Karnataka with appropriate land management practices.

Criteria applied for selection of landform management depends on factors like rainfall of the region, soil type, field slope and 
intended crop for the season. There is a need for an improved in-situ soil and water conservation and proper drainage technology particularly in deep black soils that can protect the soil from erosion throughout the season and provide control at the place where the rain falls. Tillage, nitrogen levels and irrigation greatly influence the yield and malt quality of barley. Tillage methods have a major influence on aeration, moisture and temperature of soil which in turn affect the yield and quality of crop.

Nitrogen is a constituent of amino acids, required for proteins synthesis and other related compounds; it plays a role in almost all plant metabolic processes. It is an integral part of chlorophyll responsible for plant food manufacturing through photosynthesis. So it induces rapid growth, increases leaf size and improves quality, promotes fruit and seed development.

Among the fertilizer nutrients, nitrogen is the nutrient that is absorbed in largest amount and is the most limiting factor for crop production (Dev and Chauhan 2009). The insufficient amount of nitrogen can reduce the quality below acceptable levels, while high nitrogen fertilizer rates can result in translocation of sufficient amount of nitrogen from vegetative organs to the grain, resulting in, high grain protein content.

A variety of any crop having good yield potential, resistance to insect-pest and disease sometimes becomes susceptible to such biotic factor and thus loses the yield potential. Over the time, they also start behaving differently to the applied nutrients. It is hence, desirable that varieties should be evaluated for staggered sowing and variable nutrients.

Different varieties have different yield potential requiring variable nitrogen dose. All the varieties may not be suitable for timely as well as the late sowing. The information on the suitability of barley varieties for different periods is not available as in the case of other crops, such as wheat.

Its grains contain 8-10 per cent protein and 74 per cent carbohydrates besides minerals and vitamin B-complex, it thus forms a staple food, cattle feed, malt for manufacturing of beer and other liquor products. Barley is also known to contain water soluble fiber (beta glucans) and oil compound (tocotrienols) which are found to be effective in lowering cholesterol level of blood.

This crop was grown on 6.71 lakhs hectares and recorded a production of 17.30 lakhs tonnes with an average yield of $2.58 \mathrm{t} \mathrm{ha}^{-1}$ in India during 2013-14 (Anonymous 2014). The major barley producing states in India are Rajasthan, UP, Haryana, MP and Punjab. In Uttar Pradesh it was grown on 1.56 lakhs hectares with a production of 4.50 lakhs tonnes with an average yield of $2.88 \mathrm{t} \mathrm{ha}^{-1}$ during 2013-14 (Anonymous 2014). Punjab ranked first in terms of productivity of barley during 2013-14. Due to its very hardy nature, barley can be successfully cultivated under adverse agro-climatic conditions. Barley is usually preferred crop by farmers over wheat under constrained environment (Mishra and Shivakumar, 2002).

About 75 per cent of world barley is used for animal feed and 20 per cent for malting, with the remaining 5 per cent for direct food use. In recent years the use of barley as food has gained momentum, especially in North America and Europe, gaining the label as a 'functional' food. Almost 60 per cent of the total barley produced in India is consumed as cattle feed. Barley requires cool weather during early growth and warm and dry weather at maturity. It is grown by nearly 100 countries on about 56 million hectares.The utilization of barley for malting and brewing 
industry has picked up recently with an increase of consumption of beer and other malt based products in many countries including India. Presently about 25-30 per cent of the total barley production is used in the manufacture of malt and malt extract, which is further utilized for brewing, distillation, baby foods, cocoa-malt drinks and medicinal syrups.

\section{Materials and Methods}

The present investigation was conducted at Soil Conservation and Water Management Farm, Chandra Shekhar Azad University of Agriculture and Technology, Kanpur (U.P.) during rabi season of 2015-16 and 2016-17. The experimental farm falls under the Indogangetic alluvial tract of Central Uttar Pradesh.

Geographically, Kanpur is situated in the central part of U.P. and subtropical tract of North India between latitude ranging from $25^{\circ}$ $56^{\prime}$ to $28^{0} 58^{\prime}$ North and longitude $79^{\circ} 31^{\prime}$ to $80^{\circ} 34^{\prime}$ East and is located on an elevation of about 125.9 meters above mean sea level in gangetic plain. The seasonal rainfall of about $816 \mathrm{~mm}$ received mostly from $\mathrm{II}^{\text {nd }}$ fortnight of June or first fortnight of July to mid October with a few showers in winter season.

The experiment was carried out in factorial complete randomized block design with three replications and three nutrient management i.e. $\mathrm{N}_{1}(100 \% \mathrm{RDN}), \mathrm{N}_{2}(75 \% \mathrm{RDN}$ through chemical fertilizers $+25 \%$ RDN through vermicompost) and $\mathrm{N}_{3}(75 \% \mathrm{RDN}$ through chemical fertilizers $+25 \%$ RDN through vermicompost + Azotobactor) and two varieties i.e. $\mathrm{V}_{1}$-Narmada (K-603), $\mathrm{V}_{2}$-Azad (K-125) and three level of moisture conservation practices i.e. $\mathrm{M}_{1}$-Control, $\mathrm{M}_{2}$ Dust mulch created by weeding and hoeing followed by hand hoe after 25 days of sowing, $\mathrm{M}_{3}$-Herbicide (2,4-D, 35 days after sowing)

\section{Results and Discussion}

\section{Growth Parameter}

\section{Plant stand}

Plant stand of barley under different nutrient management and moisture conservation practices was counted after complete germination. There was no statistical difference among treatments under nutrient management practices, but in moisture management practices the difference was found significant for initial stand. The highest primary stand was counted under dust mulching and lowest recorded at control. In varietal comparison variety Narmada displayed the higher primary plant stand over the cv. Azad. The similar trend was also found in plant stand, counted at final stage.

\section{Root studies}

The number of primary roots/plant was maximum (12.49) in $75 \%$ RDN through chemical fertilizer $+25 \%$ RDN through vermicompost + Azotobacter. 100\% RDN through chemical fertilizer produced the minimum primary roots/plant due to poor congenial condition of soil profile. These results are similar to the findings of Awasthi et al., (2017). Under varietal comparison, the insignificant difference was noted, however, variety Narmada produced slightly higher number of primary roots/plant. The difference between primary roots/plant in both variety was due to genetical variation. Dust mulching produced (12.41) higher number of primary root/plant than other tested moisture conservation practices. The variation in number of primary roots/plant in difference practices of moisture conservation was due to variation in availability of conserved soil moisture into soil. The $75 \%$ RDN through chemical fertilizer $+25 \%$ RDN through vermicompost + Azotobacter registered 
$(22.17 \mathrm{~cm})$ higher root spread depth, while root depth measured under $100 \%$ RDN through chemical fertilizer was minimum (Figure 4.11). The organic matter supplied through vermicompost in other two treatments was provided the congenial condition for root development from the upper layer of soil, which restricted root spread until lesser depth of soil. No variation was noted in the roots spread depth under variety Narmada and Azad. this was due to genetical character of variety. The similar results have also been reported by Awasthi et al., (2017). Dust mulching indicated the maximum depth of root spread. The poor conservation of moisture into soil in control and herbicide practices were not provided congenial condition to root spread, which promoted depth of root spread.
The lowest depth of root spread was measured $(20.55 \mathrm{~cm})$ in control and herbicide treatments. The increase in moisture conservation in soil profile under dust mulch practices, supported to the highest root depth. The results of dry weight of roots/plant under different nuteient management practices displayed the insignificant response. However, $75 \%$ RDN through chemical fertilizer $+25 \%$ RDN through vermicompost + Azotobacter produced (1.88 g) more dry weight/plant. The minimum dry weight of roots/plant was weighed $(1.72 \mathrm{~g})$ in $100 \%$ RDN through chemical fertilizer. The increase in dry weight of roots/plant in $75 \%$ RDN through chemical fertilizer $+25 \%$ RDN through vermicompost + Azotobacter may be attributed to increase in numbers of primary roots/plant.

Fig.1 Effect of nutrient management, varieties and moisture conservation practices on plant stand (per running meter) of barley
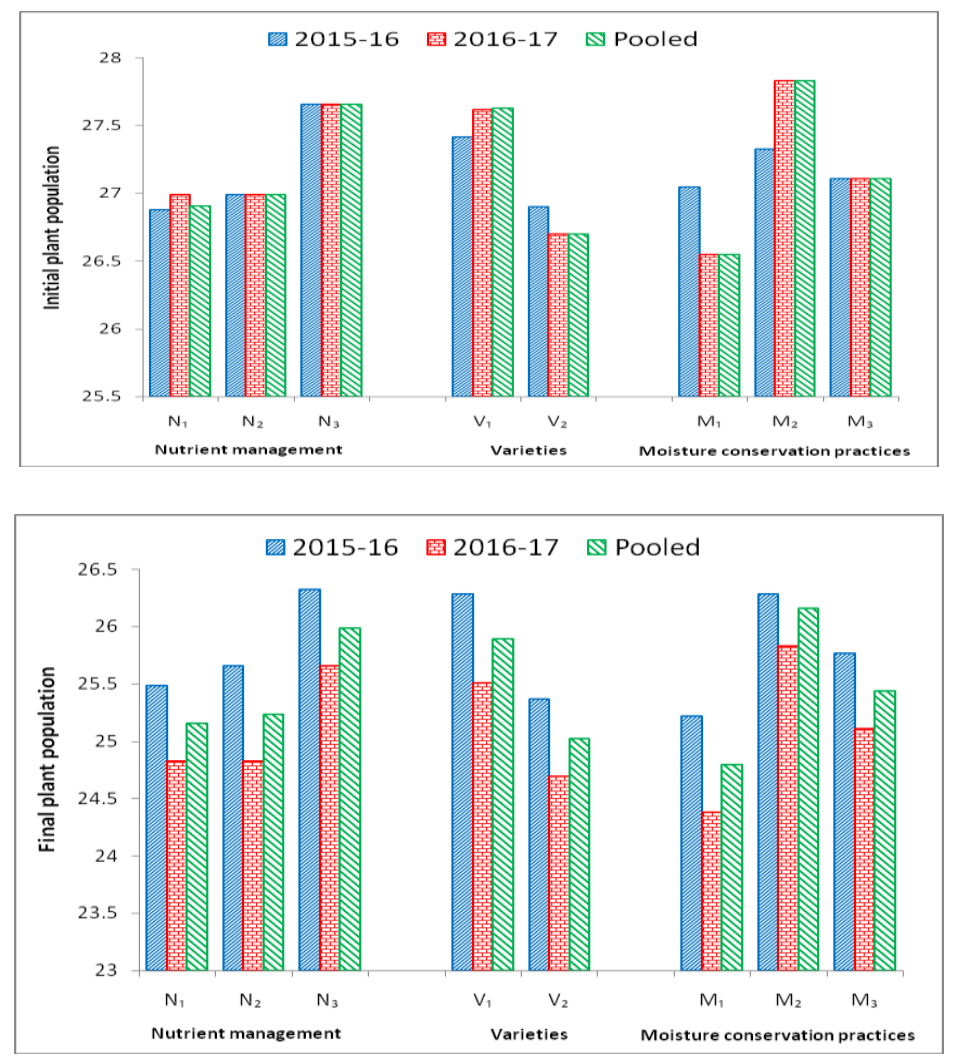
Fig.2 Effect of nutrient management, varieties and moisture conservation practices on primary roots/plant, root depth $(\mathrm{cm})$ and dry weight of roots/plant $(\mathrm{g})$ of barley
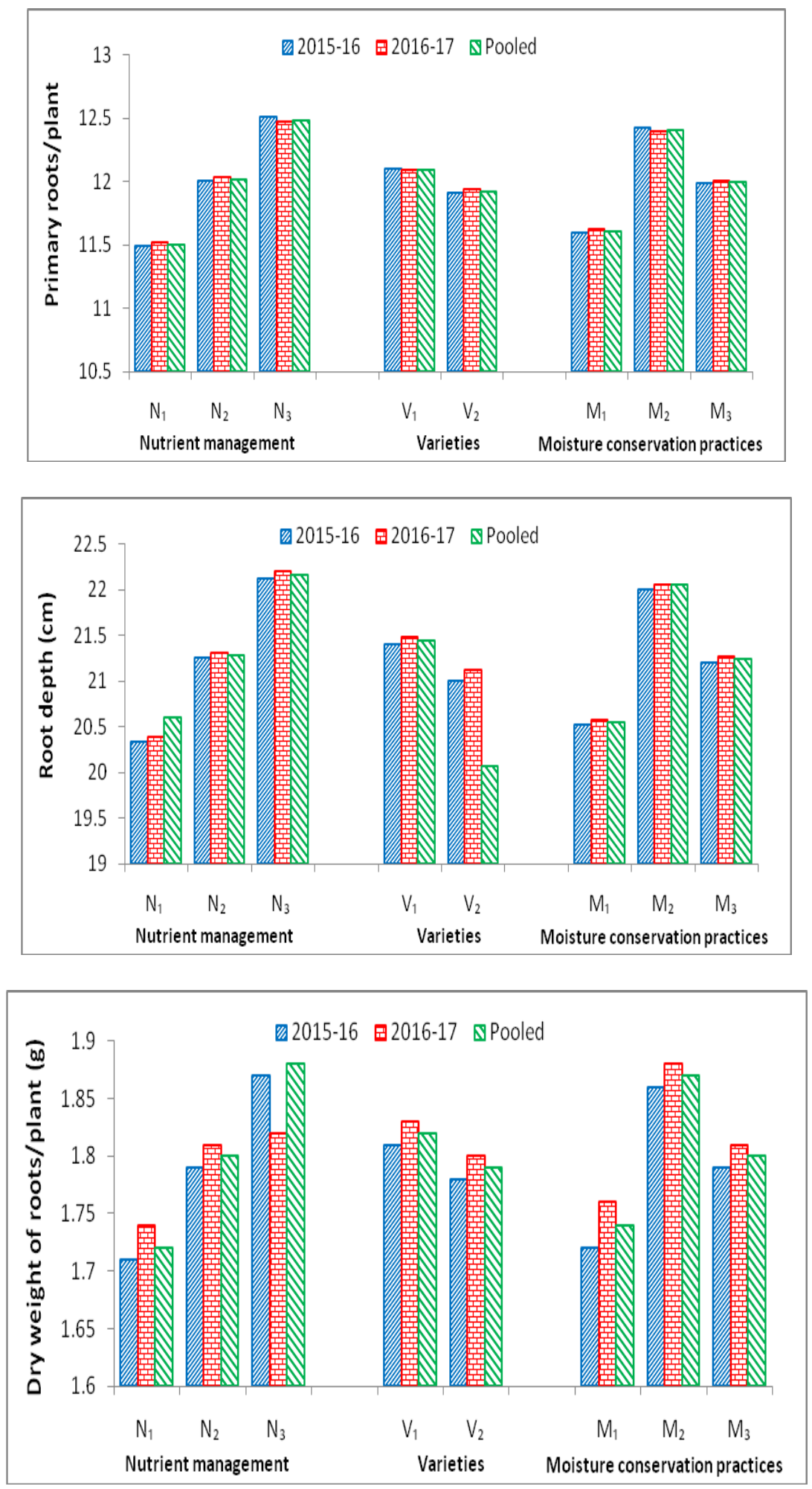
Fig.3 Effect of nutrient management, varieties and moisture conservation practices on total water use $(\mathrm{mm})$ and water use efficiency $(\mathrm{kg} / \mathrm{ha} / \mathrm{mm})$ of barley
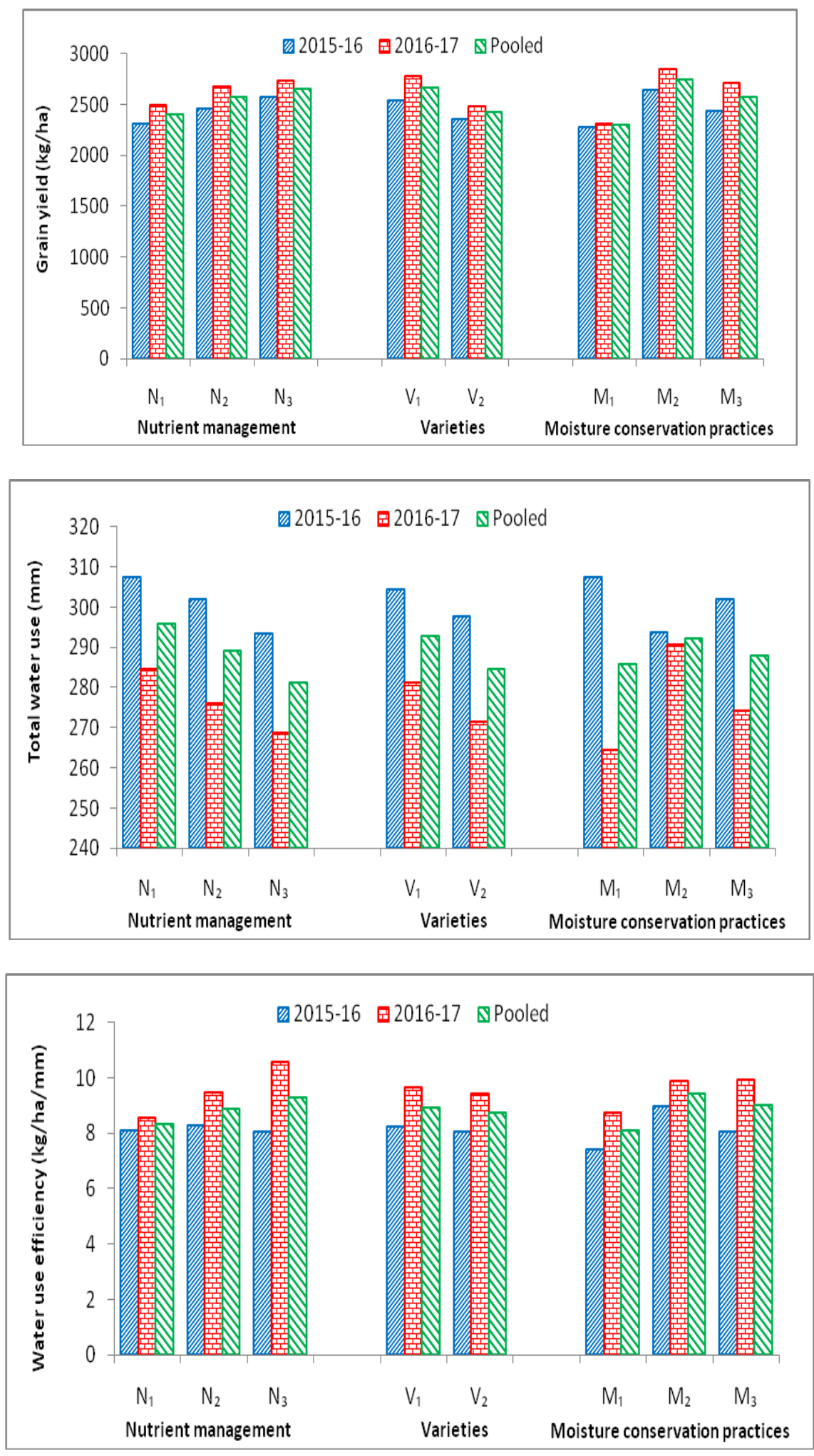
The number of primary roots/plant reduced considerably in $100 \%$ RDN through chemical fertilizer, supported to reduction in dry weight of roots/plant. Awasthi et al., (2017) also reported the variation in nutrient management practices in respect of dry weight production of roots/plant. No variation was recorded in the dry weight of roots/plant under Narmada and Azad variety. no variation in primary roots/plant was supported to the no variation of dry weight of roots/plant. The similar results have also been reported by Awasthi et al., (2017). Dry weight of roots/plant was noted maximum under dust mulching treatment. control practice exhibited minimum dry weight of roots/plant. Thus, the variation in dry weight of roots production/plant was noted among the different moisture conservation practices behaved in a similar manner to number of primary roots/plant.

\section{Water use efficiency}

Water use efficiency was recorded 9.32 $\mathrm{kg} / \mathrm{ha} / \mathrm{mm}$ of water under $75 \%$ RDN through chemical fertilizer $+25 \%$ RDN through vermicompost + Azotobacter, which was higher over other practices of nutrient management. the lowest was recorded under $100 \%$ RDN through chemical fertilizer by $8.35 \mathrm{~kg} / \mathrm{ha} / \mathrm{mm}$ of water. The water use efficiency increased with increased in grain yield of barley and moisture management practices. The variety Narmada gave (8.95 $\mathrm{kg} / \mathrm{ha} / \mathrm{mm}$ ) higher water use efficiency, while lowest water use efficiency recorded (8.75 $\mathrm{kg} / \mathrm{ha} / \mathrm{mm}$ ) in $\mathrm{Azad}$. The water use efficiency increased in cv. Narmada was due to increase in grain yield of barley. Variation in water use efficiency have also been reported by Awasthi et al., (2017).

In moisture conservation practices, dust mulching displayed $(9.44 \mathrm{~kg} / \mathrm{ha} / \mathrm{mm})$ higher water use efficiency, while lowest water use efficiency noted in control treatment. The water use efficiency increased under dust mulching was due to increase in grain production. The difference in water use efficiency have also been reported by Awasthi et al., (2017).

In conclusion the basis of two years field investigation made during Rabi season of 2015-16 and 2016-17 at Soil Conservation and Water Management Farm. C.S. Azad university of Agriculture and technology, Kanpur. The farming majority may be advocated for adoption of $75 \%$ RDN through chemical fertilizer $+25 \%$ RDN through vermicompost + Azotobacter, variety Narmada of barley and dust mulching practices of moisture conservation practices for good productivity and profitability under rainfed farming.

\section{References}

Anonymous (2014). Economics survey of India, 2013-14.

Awasthi, U.D., Singh, S.P., Mishra, P.K., Prajapati, B. And Singh, A. (2017). Productivity and profitability of rainfed barley (Hordium vulgare) crop as influenced by variety, fertility and moisture conservation. Int. J. Microbio. App. Sci., 6(6) : 2952-2957.

Dev, D and Chauhan R. S. (2009). Effect of sowing dates and nitrogen levels on growth and yield of barley (Hordeum vulgare L.).Prog Agric., 9 : 295-97.

El-Toukhy, S. A. and Abdel-Azeem, H. H.(2000). Response of barley (Hordeum vulgare) to biofertilization technology. Annals of Agricultural Science (Cairo), 2 (Special) : 539-559.

Mishra, B.N. and Shivakumar (2002). barley. In: Techniques and management of field crop production, Agrobios, India, 478 pp.

Shantveerayya, Mansure, C.P., Alagundagi, 
S.C. and Salakinkop, S.R. (2015). Productivity of barley (Hordium vulgare L.) genotypes to integrated nutrient management and broad bed and furrow method of cultivation in watershed area. International Journal of Agriculture Science, 7(4) : 497-501.

Solanki, N. S., Singh, R. R. and Chauhan, R. S. (1987). Effect of nitrogen, agrochemicals and Azotobacter inoculation with and without FYM on yield and quality of rainfed barley. Indian Journal of Agricultural Research, 21(2) : 8387.

Tiwari, D. D., Katiyar, N. K., Nigam, R. C. and Gupta, B. R.( 2008). Yield, nutrient uptake and quality characteristics of barley (Hordeum vulgare L.) as affected by graded levels of nitrogen and Azotobacter inoculation. Research on Crops, 9(2) : 243-245.

\section{How to cite this article:}

Ravi Pratap Singh and Katiyar, S. C. 2021. Studies on Nutrient Management, Varieties and Moisture Conservation Practices on Growth Parameter, Root Development and WUE in Barley (Hordeum vulgare L.) under Rainfed Condition. Int.J.Curr.Microbiol.App.Sci. 10(01): 16151622. doi: https://doi.org/10.20546/ijcmas.2021.1001.188 